\title{
Present status of conservation and management of sea turtle in Cox's Bazar district of Bangladesh
}

\author{
MA Hossain ${ }^{1}$, MI Miah* ${ }^{1}$, KR Hasan ${ }^{2}$, JJ Bornali ${ }^{1}$, M Shahjahan ${ }^{1}$ \\ ${ }^{1}$ Department of Fisheries Management, Bangladesh Agricultural University, Mymensingh 2202; ${ }^{2}$ Bangladesh \\ Fisheries Research Institute, Riverine Station, Chandpur, Bangladesh
}

\begin{abstract}
The study was conducted to know the present status of conservation and management of sea turtle in Cox's Bazar district. Data were collected by physical survey, interviewing people of the study area and from different non-government and government organizations during December 2010 to November 2011. In the present study, it was found that two species of sea turtles have been making nest in Bangladesh. Major nesting sites of turtles were St. Martin's Island, Teknaf, Bordal, Sonadia Island, Kutubdia Island, Pechardwip, Inani Beach, Moheskhali Island and Shahporirdwip. A total of 260 turtle individuals were found and the highest nesting frequency of Olive ridley (108) and Green turtles (10) were observed in February. About 21,942 hatchlings were produced and released by the hatcheries as a conservational step. Winter season was identified as nesting season for sea turtle. About $45 \%$ of the respondents thought that turtles were beneficial while other $40 \%$ of the respondents thought turtles were harmful. It was found that the nesting of sea turtles was reducing and there was lack of knowledge among the people of the study area about the importance of sea turtle conservation and management.
\end{abstract}

Key words: Conservation, Management, Nesting frequency, Nesting sites, Sea turtle

Bangladesh Animal Husbandry Association. All rights reserved. Bang. J. Anim. Sci. 2013.42 (2): 131-138

\section{Introduction}

Bangladesh (20'34'-26'38' $\mathrm{N}$ and 88'W-92'4l'E) located on the northern side of the Bay of Bengal in mainland of Asia. It is one of the resourceful countries with its wide range of marine and aquatic biodiversity. There are about 1093 marine aquatic species where $44.35 \%$ are finfish, $32.23 \%$ shellfish, $15.10 \%$ seaweeds and only $8.32 \%$ are other organisms including shrimps and sea turtles (Kabir, 2006). Seven species of sea turtle live in the world's oceans. Five species of sea turtles are found in the territorial water of Bangladesh, namely olive ridley turtle (Lepidochelys olivacea), green turtle (Chelonia mydas), hawksbill turtle (Eretmochelys imbricata), loggerhead turtle (Caretta caretta) and leatherback turtle (Dermochelys coriacea) (Smith, 1931; Shafi and Quddus, 1977; Khan, 1982 and 1987; Sarker and Hossain, 1995; Das, 1989 and Rashid, 1997). Over millions of years of their existence, sea turtles have evolved a variety of remarkable strategies for survival. They use a wide range of habitats (sandy beaches, coral reefs, sea grass beds, etc.), thus playing a critical role as flagship species for the conservation of the oceans' ecosystem and diversity. Now-a-days many of these habitats face mounting threats around the world. Sea turtles are also an important part of the traditional culture of many coastal indigenous peoples all round the world. Sea turtles migrate long distances between their feeding grounds and nesting sites. After they hatch and return to the sea, only the females return as adults to nest, males may never come back to land at all (Rashid, 1997).

The total coastline of Bangladesh measures approximately $710 \mathrm{~km}$ (ICZM, 2003). Not all the coastline is suitable for nesting (Rashid, 1997) as sandy beaches are available in sections along the mainland coast. St. Martin's I sland is a major sea turtles nesting ground in Bangladesh (Khan, 1987; Rashid, 1984; Islam, 2002). St. Martin's Island is a 600 ha island lying $10 \mathrm{~km}$ south off the southern tip of Teknaf peninsula in the Cox's Bazar District $\left(20^{\prime} 36 \mathrm{~N}\right.$ and $\left.92^{\prime} 20 \mathrm{E}\right)$. The sea turtle populations of Bangladesh appear to be severely depleted as a result of various threats, including direct exploitation for meat and eggs, habitat disturbance and fishery by catch). Three species of sea turtles have been reported to nest in Bangladesh. Among them, olive ridleys (Ahmed 


\section{Conservation and management of sea turtle}

et al. 1986; Khan 1987; Rashid 1984, 1986; Rashid and Islam 1999 and 2002) and green turtles (Khan 1982 and 1987; Rashid 1997; Rashid and Islam 1999) are common, while hawksbills are rare (Rashid 1997, Islam 2002). There is an unconfirmed nesting record of a loggerhead based on a specimen collected by the staff of the Marine Fisheries Research Institute (MFRI) in Cox's Bazar (Rashid 1997).

Sea turtles have never been prioritized in any agenda for research or conservation since Bangladesh gained independence in 1971. The only available information was in a few anecdotal notes, district gazetteers, forest department reports and newspaper reports in national dailies on the captures of sea turtles by fishermen. There were no scientific publications or systematic surveys on sea turtles until recently. Some information from sporadic surveys and observations first started to appear in the 1980s (Khan, 1982 and 1987; Rashid 1984 and 1986) and provided the impetus to conduct surveys and update available information on the station. Rashid (1997) attempted to collect information from published literature. However, much of the information was gathered over a period of two decades from irregular surveys and interviews with elderly and young fisher folk and communities living in remote coastal areas and offshore islands. Centre for Advanced Research in Natural Resources and Management (CARNRM) is the pioneer organization in Bangladesh to initiate comprehensive studies on the nesting sea turtles. In October 1996, they initiated a study and conservation programme on sea turtles (including the establishment of a beach hatchery) on St. Martin's Island in the Bay of Bengal. Although Bangladesh is a signatory of the convention on International Trade in Endangered Species of Wild Fauna and Flora (CITES), the turtles and tortoise are still indiscriminately being killed. Unsustainable exploitation of turtle is a great threat of extinction in near future (Sarker and Hossain 1995). Thus the immediate goal is to protect this species from extinction and conserve fisheries biodiversity in nature. Therefore to achieve this goal, the present work is taken within the following objectives: to know the present status of conservation and management of sea turtle in Cox's Bazar district; To understand the levels of knowledge and awareness among local communities about turtles, and to identify present management shortfall and threats for sea turtle conservation and management in Cox's Bazar district.

\section{Materials and methods}

The study was carried out under Cox's Bazar District, Bangladesh during December 2010 to November 2011. This area was selected because nesting frequency of sea turtle was very high there (Rashid and Islam 1999) and dead sea turtles have been found there repeatedly year after.

The essential data were collected from secondary data source which were collected from different national and international NGOs and responsible Government department. One hundred randomly selected people of the study area were interviewed to assess the knowledge and attitude of people towards sea turtle conservation and management. A verbal consent was sought from the participants after explaining the objectives of the study. Structured interviews were conducted with each person in the island using a questionnaire and Focus Group Discussion (FGD) with local communities. Photographs of sea turtles and sea turtle conservation related activities were taken whenever necessary to describe the community participation in the conservation and management of sea turtle in the island.

The information was accumulated, grouped and interpreted according to the objective as well as parameters. Some data contained numeric and some contained narrative facts. The collected data were then edited, summarized and graphically analyzed with MS excel.

\section{Results}

\section{Olive ridley turtles}

Olive ridley had been found to nest on sandy beaches all along the mainland coast of Cox's Bazar District and adjoining islands on the southcentral coast; Inani, Kochopia, Bordal, Monkhali and southern Teknaf along the southeastern mainland coast of Teknaf peninsula and Sonadia Island, Kutubdia Island, Moheskhali I sland and St. 
Martin's Island on the southeast coast. It had been recorded nesting in the central islands and mainland beaches. It is grayish-brown as juveniles, olive green as adults, length: $50-75 \mathrm{~cm}$ (smallest of the ocean-going turtles), weight: about $50 \mathrm{~kg}, 6-9$ costal scutes, 5 pairs of coastal plates and 3 or 4 inframarginal scutes. Inframarginal scutes have I pore near the back edge, first coastal plate touches neck, almost circular shell (Figure 1).

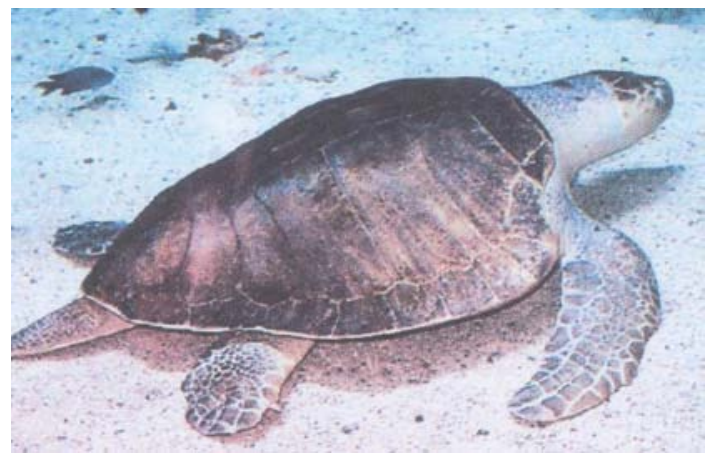

Figure 1. Olive ridley turtles

\section{Green turtles}

Green turtles had been found to nest on the mainland coasts and on island beaches. But they were found less widespread than olive ridleys. It was also reported they were found nesting southcentral island beaches, mainland beaches in the southeast (from Cox's Bazar to Teknaf) and also on some coastal islands like St. Martin's, Sonadia, Kutubdia, Hatiya and Sandweep islands. It is brown (name derived from the color of its green fat), hatchlings almost black, but lighten in color within their first year, length: $80-120 \mathrm{~cm}$, weight: $130-250 \mathrm{~kg}, 4$ coastal scutes, none of which overlap, pair of scales at the front of head, foreflippers one claw each (Figure 2 ).

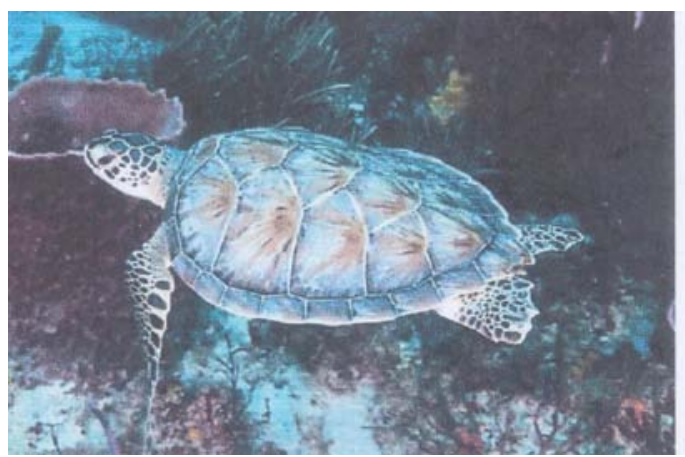

Figure 2. Green turtles

\section{Hawksbill turtles}

From the secondary data, it was found that Hawksbill turtle was a rare visitor to the beaches of Bangladesh. Based on unconfirmed reports, Hawksbill turtle was expected to be found but there was no sign of nesting Hawksbill turtle in this study area during my study period. It is dark, greenish-brown, juveniles have the "tortoiseshell" pattern, length: $55-95 \mathrm{~cm}$, weight: around $55 \mathrm{~kg}$, 4 pairs of overlapping, sharp scutes on the edges of its shell, Particularly narrow jaw, upper jaw is overhanging, Front flippers with 2 claws on each, Males: long and thick tails, bigger claws and more concave plastron (Figure 3 ).

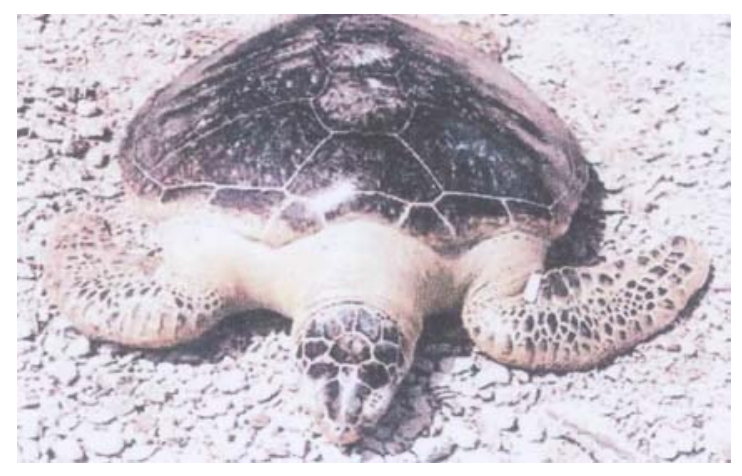

Figure 3. Hawksbill turtles

\section{Nesting sites of turtles in Cox's Bazar}

There were some beaches where nesting of sea turtles was not common for either natural formation of beaches or due to coastal development. The major nesting sites identified during the study period in Cox's Bazar District are listed in Table 1.

Table 1. Nesting sites of sea turtles in Cox's Bazar district

\begin{tabular}{|c|c|}
\hline Name of the location & Information obtained from \\
\hline St. Martin's I sland & \multirow{7}{*}{$\begin{array}{l}\text { Personal observation, } \\
\text { interview of the local } \\
\text { people, and interview of } \\
\text { the researcher }\end{array}$} \\
\hline Teknaf & \\
\hline Bordal & \\
\hline Sonadia island & \\
\hline Kutubdia island & \\
\hline Inani & \\
\hline Moheskhali & \\
\hline
\end{tabular}

\section{Nesting frequencies of sea turtle}

It was observed in the study area that nesting of olive ridley was higher than green turtle at St. 


\section{Conservation and management of sea turtle}

Martin's I sland in Cox's Bazar district. A total of 260 turtles were recorded to nest in that area. The highest nesting frequency of olive ridley (108) and green turtles (10) were observed in February (Table 2). There was no olive ridley found in May, June, July, August and September. No green turtles were found in April, May, June and August. The nesting of Hawksbill turtles or other sea turtles were not found at the period of the study.

Table 2. Nesting frequencies of sea turtles in Cox's Bazar district

\begin{tabular}{|l|c|c|c|c|c|c|c|c|c|c|c|c|}
\hline $\begin{array}{l}\text { Name of } \\
\text { turtles }\end{array}$ & $\begin{array}{c}\text { Dec } \\
/ 10\end{array}$ & $\begin{array}{c}\text { Jan } \\
/ 11\end{array}$ & $\begin{array}{c}\text { Feb } \\
/ 11\end{array}$ & $\begin{array}{c}\text { Mar } \\
/ 11\end{array}$ & $\begin{array}{c}\text { Apr } \\
/ 11\end{array}$ & $\begin{array}{c}\text { May } \\
/ 11\end{array}$ & $\begin{array}{c}\text { Jun } \\
/ 11\end{array}$ & $\begin{array}{c}\text { Jul } \\
/ 11\end{array}$ & $\begin{array}{c}\text { Aug } \\
/ 11\end{array}$ & $\begin{array}{c}\text { Sept } \\
/ 11\end{array}$ & $\begin{array}{c}\text { Oct } \\
/ 11\end{array}$ & $\begin{array}{c}\text { Nov } \\
/ 11\end{array}$ \\
\hline $\begin{array}{l}\text { Olive } \\
\text { Ridley } \\
\text { turtle }\end{array}$ & 10 & 98 & 108 & 7 & 1 & 0 & 0 & 0 & 0 & 0 & 5 & 7 \\
\hline $\begin{array}{l}\text { Green } \\
\text { turtle }\end{array}$ & 2 & 6 & 10 & 1 & 0 & 0 & 0 & 1 & 0 & 1 & 1 & 2 \\
\hline $\begin{array}{l}\text { Hawksbill } \\
\text { turtle }\end{array}$ & 0 & 0 & 0 & 0 & 0 & 0 & 0 & 0 & 0 & 0 & 0 & 0 \\
\hline
\end{tabular}

At the period of the study, different initiatives for conservation and management activities of sea turtles were identified. The government of Bangladesh and national and international NGOs had taken many steps for fulfilling their goals to protect sea turtle population and their environment. Some initiatives were identified which were performing by Govt. and NGOs are presented in below: Establishment of rules and regulation; Declaration of Ecologically Critical Areas; Funding facilities; Minimization of coastal development; Sustainable resource management; Various types of research; International agreements, conventions, treaties and protocols signing; Establishment of ecotourism in that area and Coordination of works with other national and international NGOs etc.

Seven hatcheries had been found five areas of the Cox's Bazar coast viz., 1. Sonadia East village Beach, Moheshkhali, Cox's Baza by CV*1BMP, MLA; 2. Sonadia West village Beach, Moheshkhali, Cox's Bazar by CWBMP, MLA; 3. Pechardwip Beach, Teknaf Peninsular Beach, Cox's Bazar by CWBMP, MLA; 4. Samchari Beach, Teknaf Peninsular Beach, Cox's Bazar by CWBW, MLA; 5. Shahporirdwip, Teknaf Peninsular Beach, Cox's Bazar by CWBMP, MLA; 6. St. Martin's Island
Beach, Cox's Bazar by CNRS and 7. St. Martin's Island Beach, Cox's Ban by SMP, CMMMP. Sea turtle hatcheries had been installed by Govt. and different NGOs at the sites mentioned above. Different NGOs were working for both in situ and ex situ conservation through hatching of turtle eggs. It was found that for the conservation purpose mainly ex-situ conservation was performed in the study area through eggs collection and hatching in the hatcheries. The total amounts of 23850 eggs were incubated in the study period and 21942 hatchlings were produced and released.

It was found that some people of the study area were engaged with turtle business. Most of the people said that Maghs, Hindus ate turtle eggs. They said that Hindus in their area mainly ate the turtle and its eggs. They also said that some local people of their area collected turtle eggs and sold to their consumers. Some of turtle business activities were identified and those are presented in Table 3.

Table 3. Turtle business activities in Cox's Bazar district

\begin{tabular}{ll}
\hline Turtle/eggs or shell & Consumers/Buyers \\
\hline Eggs & Maghs, Hindus, Tourist \\
\hline Meat of turtle & $\begin{array}{l}\text { Mainly hindus but } \\
\text { sometimes tourist }\end{array}$ \\
\hline Turtle shell & Mainly tourist \\
\hline Dried turtle & $\begin{array}{l}\text { Local people, people from } \\
\text { outside the area. }\end{array}$ \\
\hline
\end{tabular}

One hundred people from the study area were selected randomly for taking interview. Wide ranges of indicators were collected in various aspects of knowledge and attitude of the people on sea turtle. Most of the respondents answered that they didn't know much about the sea turtle although everyone of the respondents saw turtles in their area. Majority of the fishermen claimed that turtles reduced the fish population(some of them told that they heard to eat jelly fish and waste materials by turtles but they didn't believe the most of the students had idea that sea turtle ate jelly fish and waste materials. Majority of local people had no clear idea about sea turtles and its importance. They answered that turtles are good creature of Allah and turtles added 
beauty of their area. It was found that majority of the respondents $(89 \%)$ could differentiate turtle's eggs from other eggs (hens or ducks). Rest $11 \%$ couldn't identify turtle's eggs (Figure 4). Most of the people answered that turtles were found in the tourist (winter) season (64\%) while a large number of people (24\%) didn't know much about it. Some of the respondent $(6 \%)$ answered that turtles could be found in rainy season and few other $(6 \%)$ seasons like late rainy or all round year (Figure 5).

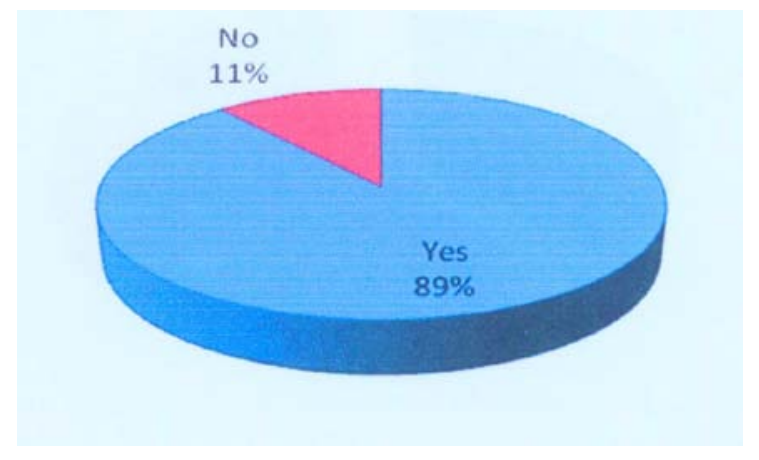

Figure 4. Knowledge about identifying eggs

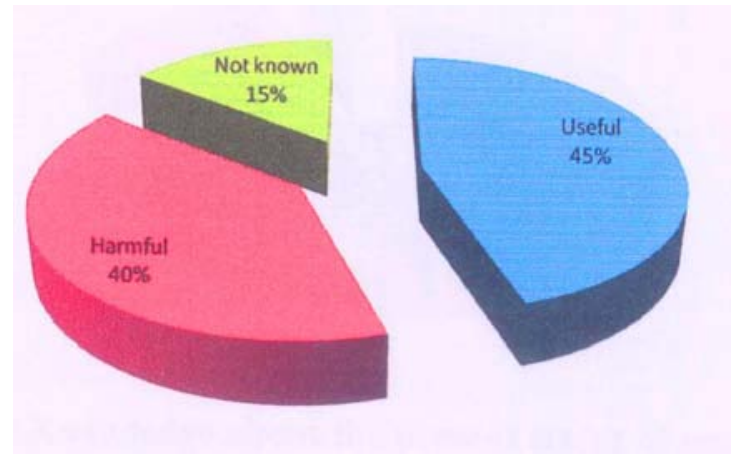

Figure 5. Knowledge on nesting season of turtle

About $45 \%$ of the respondent thought that turtles were beneficial. Most of them replied that turtle ate waste, insect of the sea and kept clean the environment. About $40 \%$ of the respondent answered turtles were harmful because they ate fish and cut nets and created hazards. This group was constituted mostly by fisherman. The rest of the respondents (15\%) answered that they were not sure whether sea turtle was beneficial or harmful (Figure 6).

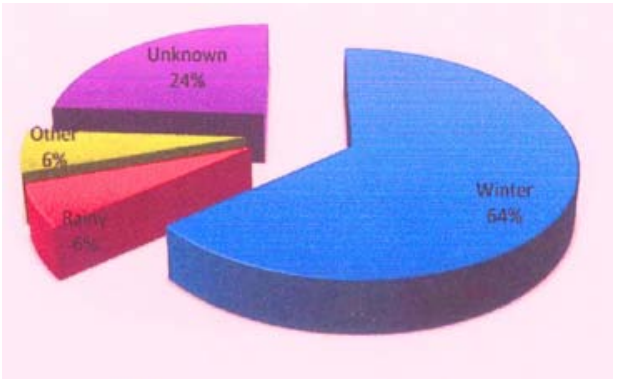

Figure 6. Knowledge about sea turtle beneficial or harmful

About $62 \%$ of the respondents considered that turtle as a bad sign for them and $38 \%$ of the respondents didn't think so. Those answered 'turtles as a bad sign' indicated that if they saw turtle during going to fishing total amount of catch was significantly reduced. To get rid of these problem then he had to arrange religious function (Muslim arrange 'MI LAD) (Figure 7).

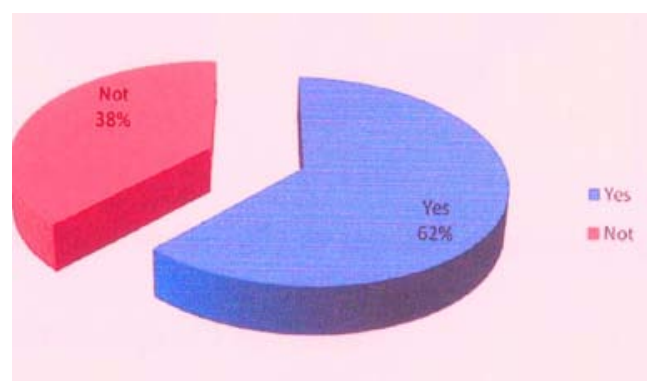

Figure 7. Knowledge about turtle is a indicator of bad sign

About $78 \%$ of the respondent told that the abundance of sea turtle declined or reduced comparing to the past while $18 \%$ of the respondent said the abundance was unchanged. Only $4 \%$ told that turtles increased comparing to the past (Figure 8).

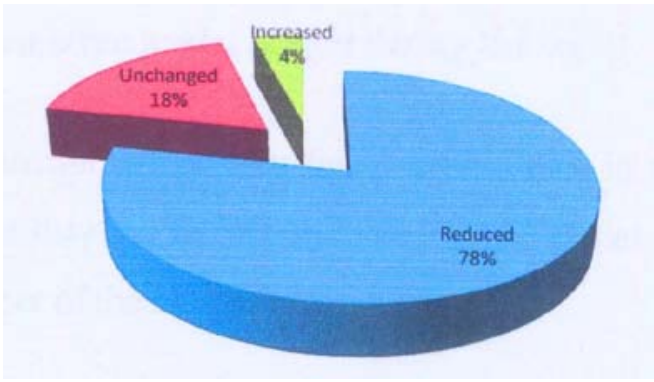

Figure 8. Knowledge about the present status of sea turtle 


\section{Conservation and management of sea turtle}

In the study area, several threats were identified through direct observation and from the answer of the respondents. Majority of the respondents said that turtles were declining day by day. Most of the respondents claimed that fisherman killed the turtles during fishing to save their value able nets. The rests are listed in Table 4.

Table 4. Threats to sea turtle in Cox's Bazar District

\begin{tabular}{|c|c|}
\hline Area & Threats \\
\hline In the sea & $\begin{array}{l}\text { 1. Fisherman killed turtles if it } \\
\text { entangled in net } \\
\text { 2. Collision with fishing vessels were } \\
\text { also common and sometimes } \\
\text { intentional } \\
\text { 3. Populations of others eat the } \\
\text { turtles } \\
\text { 4. Pollution (oil spills and other } \\
\text { pollution) and disposal of solid } \\
\text { domestic and machinery waste }\end{array}$ \\
\hline $\begin{array}{l}\text { On nesting } \\
\text { beaches }\end{array}$ & $\begin{array}{l}\text { 1. Nesting females were occasionally } \\
\text { killed by stray dogs and jackals on } \\
\text { coastal islands } \\
\text { 2. Traditional utilization by local } \\
\text { coastal communities } \\
\text { 3. Physical alterations and } \\
\text { development of infrastructure } \\
\text { along thecoast } \\
\text { 4. Utilization of beaches for drying } \\
\text { fish and mending fishing nets } \\
\text { 5. Beach lighting had also increased } \\
\text { which disturbs nesting females and } \\
\text { is disorients hatchlings }\end{array}$ \\
\hline $\begin{array}{l}\text { Climate } \\
\text { change }\end{array}$ & $\begin{array}{l}\text { 1. Habitat loss } \\
\text { 2. Species loss, etc }\end{array}$ \\
\hline
\end{tabular}

\section{Discussion}

By studying of present status, distribution and nesting of sea turtle in Cox's Bzaar, it was found that two species of sea turtles have been nest in Bangladesh. Among them Olive ridleys were common and green turtles were uncommon while hawksbills did not found at the period of the study. Islam et al. (1999) reported that there were five species found in the territory of Bangladesh. Among them, three species of marine turtle nested in Bangladesh (Rashid 1984; Ahmed et al. 1986; Khan 1987; Rashid and Islam
1999). At the study period, different activities for conservation and management activities of sea turtles were identified. The majorities of their activities were monitoring of nesting and dead Sea turtles, In-situ and Ex-situ breeding program throughout the $140 \mathrm{kms}$ of Coastline, habitat mapping and scientific morphometric data collection with the help of community awareness among the community people, local children's education through school program, by catch awareness program with the offshore fishermen through training and motivation, some of their other efforts were also satellite tracking, tagging, off shore survey etc. Sea turtle tagging and tracking process by various NGOS were also identified at the time of study. Rashid and Islam (2006) mentioned that tagging of marine turtles at St. Martin's Island and other areas started in 2000 and tagging techniques followed (Balazs, 1999).

It was observed that turtle were found in the tourist season which is supported by Islam (2002) who found the nesting season runs from October to April. In the present study, majority of the respondent did not know about the beneficial of turtle while few respondent known as harmful. Islam et al. (1999) identified that the fishing community considered the sighting of a turtle or a turtle getting entangled in the fishing nets as a bad sign. On the other hand majority $(73 \%)$ of the respondent had a positive attitude towards sea turtle conservation in Srilanka which might be due to religious condition of the people.

In the study area several threats were identified through direct observation from the answer of the respondents. Majority of respondents said that turtles were declining day by day. Most of the respondents claimed that turtles were declining day by day. Most of the respondents claimed that fisherman killed the turtles during fishing to save their valuable nets. Some threats were identified from the present study like traditional utilization of turtle product, killing of nesting of nesting female through stray dogs and jackals on coastal islands, incidental turtle mortality occurs in trawl nets, gill nets, and mesh nets where the turtles get entangled and cannot escape, coastal 
development, artificial lights etc. Rashid and Islam (2006) identified that the threats to sea turtles in Bangladesh were stray dogs on nesting beaches, incidental capture of turtle, artificial lights, manmade physical alterations such as barriers around the beach etc. Sarker (2009) found his study that thousands of sea turtles come to shallow water areas of the Bay where the males mate with females lay eggs on the beaches nearby. They may lose their breeding ground due to inundation by sea level rise caused by climate change.

\section{Conclusions}

Five species of sea turtles are found in the territorial water of Bangladesh. Sea turtles have never been prioritized in any agenda for research or conservation since Bangladesh gained independence in 1971. The only available information was in a few anecdotal notes, district gazetteers, forest department reports and newspaper reports in national dailies on the captures of sea turtles by fishermen. Some information from sporadic surveys and observations first started to appear in the 1980s. CARINAM is the pioneering organization to study and monitor the nesting sea turtles in Bangladesh and then the Government and other research organizations have taken several steps. Government should take initiatives for community based conservation and management including various awareness programs. An additional syllabus or program can be taken in the school to aware of the students for sea turtle conservation. As nesting ground was reduced for infrastructural development on beaches, measures should be taken for solving this problem. Bangladesh is the mostly vulnerable country for climate change; different methods should be identified for climate change adaptation to protect the biodiversity including sea turtle.

\section{Acknowledgement}

The authors wish to express their appreciation to Dr. SMA Rashid, chief executive of Centre for Advanced Research in Natural Resources and Management (CARINAM) for his assistance and cordial help to complete this research work.

\section{References}

Ahmed B, Huda KMN, Asmat GSM (1986). The breeding of the Olive ridley Lepidochelys olivacea Eschscholtz a St. Martin Island, Bangladesh. Bangladesh J ournal of Zoology, 14: $59-68$.

Balazs GH (1999). Factors to consider in the tagging of Sea turtles. In: Eckert $\mathrm{KL}$, Bjorndal kA, Abreu-grobois FA and Donnelly M. (9 eds). Research and management techniques for the conservation of sea turtles, Washington DC. IUCN/SSC marine Turtle Specialist Group publication, 4: 101-109.

Das I (1989). Sea Turtles and Coastal Habitats in South - Eastern Bangladesh. Project report to the sea turtle Rescue Fund/Center for marine Conservation, Washington DC. P. 12-18.

ICZM (2003). Integrated Coastal Zone Management Project Report. On-line document.

Islam MZ (2002). Marine turtle nesting at St. Martin's I sland, Bangladesh. Marine Turtle Newsletter, 96: 19-21.

Khan MAR 1982. Wildlife of Bangladesh: A Checklist. University of Dhaka, Dhaka, P. 174.

Khan MAR (1987). Bangladesher banya prani Vol.1. Dhaka: Bangla academy. P. 168. the Newsletter of Chelonian Conservationists and Biologists, 1: 1-9.

Kabir H (2006). Marine fisheries in Bangladesh an overview. On line document.

Rashid SMA (1984). Jolpai rong shamudrik kasim. Poribesh Porikroma.Bulletin of the Wildlife Society of Bangladesh, 1: 3-6.

Rashid SMA (1986). Conservation plan for marine turtles in St. Martin's Island, Bangladesh. Proceedings of the $6^{\text {th }}$ National Zoological Conference, Chittagong University, Bangladesh, P. 8.

Rashid SMA (1997). Bangladesh National Report for the Northern Indian Ocean Sea Turtle Workshop and Strategic Planning.13-18, January 1997. Bhubaneswar, India, P. 16.

Rashid SMA, Islam MZ (1999). Establishing marine turtle hatchery in saint main Island, Bangladesh. Proceedings of the $4^{\text {th }}$ Asia pacific NGOs Environmental Conference, 


\section{Conservation and management of sea turtle}

Singapore, Department of Biological Sciences, National University of Singapore, P. 255-264.

Rashid SMA, Islam MZ (2006). Status and conservation of marine turtles in Bangladesh. In: Shanker K, Chowdhury BC (eds.) Marine Turtles of the Indian Subcontinent. Universities Press, New Delhi, India, P. 200-216.

Sarker MSU (2009). Climate Change Impact on Bangladesh Published in daily newspaper in Bangladesh. On-line document.

Sarker SU and Hossain ML (1995). Population, Ecobiological status, Captive propagation and Conservation problems of Lissemys punctata in Bangladesh. International congress of Chelonian conservation. France, P. 43-46.

Shafi M and Quddus MA (1977). Bangladesher matshya swampada: Part 4.Kasim, Kaitta Samudrik Kasim. Bangla Academy Bignan Patrica, 3: 14-36.

Smith MA (1931). The fauna of British India, including Ceylon and Burma. Reptilia and Amphibia. Loricata, Testudines. Iondon: Taylor and Francis. 1: 185. 